\title{
LetTer: PreVEntion OF THE SPREAD OF INFECTION - THE NEED FOR A FAMILY-CENTRED APPROACH TO HYGIENE PROMOTION
}

\author{
Kevin Pollock (kevin.pollock@hps.scot.nhs.uk) ${ }^{1}$, R House $^{1}, \mathrm{~J} \mathrm{M} \mathrm{Cowden}^{1}$ \\ 1. Health Protection Scotland, Glasgow, United Kingdom
}

To the editor: We read the article 'Prevention of the spread of infection - the need for a family-centred approach to hygiene promotion' by Bloomfield et al. [1] with interest. While the authors raise valid points with regards to a more concerted approach to personal hygiene, there are two issues in the report which we wish to respond to.

Bloomfield et al. state that public health practitioners should be less ambiguous on issues such as the hygiene hypothesis which should be communicated to the public. Some studies suggest a role for the hygiene hypothesis in promotion of inflammatory bowel disease (IBD), whereby childhood exposure to infections confer protection against autoimmune disease [2,3]. However, an ecological study in a paediatric population demonstrated an association between cattle density and incidence of $\mathrm{E}$. coli 0157-mediated haemolytic uraemic syndrome (HUS) [4], and the importance of environmental transmission for this pathogen cannot be ignored [5]. Therefore, the concept of 'good dirt; bad dirt' remains a contentious area, especially in public health. Promulgating the hygiene hypothesis and related environmental issues to the public will serve only to confuse rather than to inform.

Bloomfield et al. also suggest that poor hygiene is a contributory factor in the spread of several pathogens including legionella without providing supporting references. In our experience, typical and atypical sources of legionella do not involve routes of transmission which can be exploited by improving hygiene and we are not aware of any references to support this. Indeed, it is current practice in Scotland for public health practitioners managing legionella outbreaks to ensure, within press statements, that the public are reassured legionella cannot be spread through person-person contact or through poor hygiene.

We agree with Bloomfield et al. that promotion of personal hygiene should start from within the home as the simple task of hand washing has been shown to be one of the most effective means of controlling the transmission of infectious organisms from hands and beyond [6].

\section{References}

1. Bloomfield S, Exner M, Fara GM, Scott EA. Prevention of the spread of infection - the need for a family-centred approach to hygiene promotion. Euro Surveill. 2008;13(22):pii=18889. Available from: http://www.eurosurveillance.org/ ViewArticle.aspx?ArticleId $=18889$

2. Gent AE, Hellier MD, Grace RH, Swarbrick ET, Coggon D. Inflammatory bowel disease and domestic hygiene in infancy. Lancet. 1994;343(8900):766-7.

3. Amre DK, Lambrette P, Law L, Krupoves A, Chotard V, Costea F, et al. Investigating the hygiene hypothesis as a risk factor in paediatric onset Crohn's disease: a case-control study. Am J Gastroenterol. 2006;101(5):1005-11.

4. Haus-Cheymol R, Espie E, Che D, Vaillant V, DE Valk H, Desenclos JC. Association between indicators of cattle density and incidence of paediatric haemolytic uraemic syndrome (HUS) in children under 15 years of age in France between 1996 and 2001: an ecological study. Epidemiol Infect. 2006;134(4):712-8.

5. Howie H, Mukerjee A, Cowden J, Leith J, Reid T. Investigation of an outbreak of Escherichia coli 0157 infection caused by environmental exposure at a scout camp. Epidemiol Infect. 2003;131(3):1063-9

6. Health Protection Scotland. Scotland's National Hand Hygiene Campaign. Available from: http://www.washyourhandsofthem.com/

This article was published on 5 June 2008.

Citation style for this article: Pollock K, House R, Cowden JM. Letter: Prevention of the spread of infection - the need for a family-centred approach to hygiene promotion Euro Surveill. 2008;13(23):pii=18893. Available online: http://www.eurosurveillance.org/ ViewArticle.aspx?ArticleId $=18893$ 